\title{
Impact of the Case Study Method on the Job Performance of Business Graduates: A Case Study of Institute of Business Administration Sukhur
}

\author{
Muhammad Shahzad Iqbal (Corresponding author) \\ Lecturer, Department of Business Studies \\ The University of Faisalabad, Faisalabad
}

Tel: 92-300-866-0601Ｅ-mail: shahzad.iqbaal@gmail.com

Faiz Muhammad Shaikh

Assistant Professor

SZABAC-Dokri

Larkana-Sindh-Pakistan

E-mail: faizmuhammed_2000@yahoo.com

Muhammad Sohail Nazar

Assistant Professor

Department of Management Sciences

Islamia Unversity Bahawalpur, Pakistan

E-mail: Sohail_nazar@yahoo.com

\begin{abstract}
The current research investigate the impact of case studies based business case studies on the market performance of Institute of Business Administration (IBA) Sukhur graduates and how they were applying those cases to practical environment. A complimentary survey was conducted from 100 IBA-Sukkur graduates by using simple random technique. A structural questionnaire was developed as an instrument tool for collecting data. It was revealed that case studies have positive impact on the job performance and resolving various management problems. It increased the vision of the student by applying various cases in daily routine life. It was further revealed that case based studies have also impact on the personal development of the student when they are solving the different cases in different situations for different firms or organizations. From last couple of years this method is pretty popular among the students, and they applied all the case studies in local environment and teachers are importing the case studies and their practical touches of different cases. It also helps the graduates when they are going for the jobs, and it has the positive relationship with the job performance. It was suggested that institutes must develop their own cases that focus on the Pakistani or Asian Environment.
\end{abstract}

Keywords: Case study, Method, Job performance, Business education

\section{Introduction}

The purpose of this research that how case study method play a key role in the job performance of the graduates of business, when they are working in different fields and how help their in job satisfaction. After graduation how internship helps them in getting job and builds their leadership qualities when they are working in the external environmental. We have conducted interviews from fifty firms and organizations regarding the impact of case study teaching method on performance of graduates of business from Sukkur-IBA. In the process of answering this overall question, we also concerning student's priorities in time allocation versus how firms feel students should allocate their time. We also consider how these allocation decisions differ by certain student's characteristics such as gender and GPA, and by certain firm characteristics, such as type of firm (e.g. food manufacturer) and sales. In the following section we review the literature. Knowledge gaps exists not so much regarding what should be done (what is good)as they do regarding how intensively a student should engage in an 
activity.

The literature examining University education in relation to case study approach and how its impact on the job performance. With the exception of some recent important work by Barkley and Barkley, stock and Sylvie's, and F.M..Shaikh little is known about the relationship between the case studies method impact starting salary and skill sets or indicators. Given that many students are getting high paying jobs, it is important that professors be able to provide the most accurate information available regarding the value of alternative career preparation steps.(at el Barkley). The purpose of this research to address the student's potential when they are working in different fields and how help the case approach in the respective job performance. After graduation how internship help them in getting job and build their leadership qualities When they are working in the external environmental. We have conducted several interviews from more than fifty firms and organizations regarding the performance of graduates of business from IBA-Sukkur. In the process of conducting interviews with employers regarding the graduates of business administration and their how they are working in the practical environment, the employers were satisfied with the performance of the business graduates, according to the survey we found that the new graduates of business has strong potential and employers were very much satisfies, such as type of firm (e.g. food manufacturer) marketing, banks, multinationals and sales. In the following section we review the literature. Many different student characteristics are positively associated with current and starting salary level. Knowledge gaps exists not so much regarding what should be done (what is good) as they do regarding how intensively a student should engage in an activity

\section{Current Salary Models}

The analyzing record of 100 graduates of business and are working in the technical, non-technical, government as well private organization. Examine their potential in job market and case approach help them regarding their personal as well as their impact on the job performance. We have randomly selected 200 graduates from Department of Business Administration Sukkur-IBA from graduate batches of, 1995 to, 2008. However, job search through personal relationship was found to be positive associated with starting salaries, where as job search through one's work experience was positively associated with starting salary.

\section{Survey design and data}

The student must know the benefits from each activity to allocate time optimally across activities. This type of information potentially cab be obtained in one or two ways: (1) use observational data on salaries and activities to estimate the benefits associated with each activity; (11) survey employers and ask how they would rank alternative activities in terms of importance. Not surprisingly, each approach has its advantages and disadvantages. The literature to date has focused on the first approach of using observational data to estimate the benefits from each activity. Starting salary is regressed on several determinants such as GPA percentage, and case analysis ability then inferences are drawn regarding the marginal impact of the variable on the starting salary. The advantage of this approach is that the data reflects actual market conditions and salary offers.

The alternative way of ascertaining how employers value different characteristic of the students is to conduct a survey and ask them directly. The main disadvantage of this approach is that answers to surveys may not be the same as actual employer behavior. However, the advantage is that the employer and student's valuations are not confounded in the measurement. The survey approach should therefore not to be considered a substitute for observational data based studies, but rather should be considered complementary approach that may shed a different light on the same issue.

\section{Employer Dataset}

Survey dataset were collected via two separate sampling efforts, one pertaining to employers and the other pertaining to business graduates-students of Sukkur-IBA. The employer data were collected from Organizations, firms, food market, marketing, banks, multinationals, food chains and was intended to correspond to the job market served by Gradates of business administration department IBA-Sukkur. Employers selected to participate in the study were those with a national reputation in their industry segment. Once cooperating individual was identified, a one-page questionnaire was fixed to that individual. Occasionally, firms returned a completed survey on the same day. Those firms not responding were called again or sent additional faxes. The producer was to continue contacting each employer until receiving either a completed questionnaire or a refusal. In all cases, those responding had an intimate knowledge of their firms hiring practices. In smaller firms the questionnaire was usually completed by one of the company owners. In large firms the questionnaire was often completed by some one in personnel department who specialized in hiring decisions. In all cases, an effort was made to find a person with appropriate authority with in each firm. The firm's survey was administered during a period extending from the fall 2004 to spring 2005. In total 100 different firms were contacted of which 60 firms 
participated for a response rate of over $60 \%$. As in all survey work, non-response bias warrants cautious inference.

\section{Students Dataset}

How closely do these firm's hiring practices compare to students perceptions? Seeking answer to this question, during the fall of 1999 a student survey was conducted in the classes taught by the management sciences department IBA-Sukkur. As with the firms, students were asked the same question regarding time allocation across the five alternative salary enhancement activities. Students were also asked to supply background information regarding their graduation class year, current GPA and their graduate school plans. Both the mean and standard deviations are presented for each student characteristics. Forty percent of the students were in the class of 1996. An additional 24\% were in class 2000 and $22 \%$ were in class of 2005 and $27 \%$ of class 2006 and $30 \%$ from class $2007-08$. Seventy eight percent of the students surveyed were male. The average GPA was 2.86 on a 4.0 scale.

\section{Students Model and Results}

The statistical model for the student data takes the same general form as the firm model, but the interaction design matrix is defined differently. The student model is of the same form.

$$
\mathrm{Y}=\mu+\mathrm{X}_{1} \beta_{1}+\mathrm{X}_{2}\left(\mathrm{X}_{1}\right) \beta_{2}+\varepsilon
$$

Where now $\mathbf{Y}$ is the $\boldsymbol{m} \boldsymbol{n} \boldsymbol{x} \mathbf{1}$ vector of allocation time stated by students $\boldsymbol{\mu}$ is the overall allocation time mean for students, $\mathbf{X} \mathbf{1}$ is a $\boldsymbol{m} \boldsymbol{n} \boldsymbol{x}$ vector of main or treatment effects (i.e the five time allocation categories ) $\mathrm{X}_{2} \mathrm{X}_{1}$ is a $\boldsymbol{m n}$ $x \boldsymbol{m} \boldsymbol{k}$ matrix of interaction of cross effect between the student characteristics (i.e classes of 1995-2004 batches) male GPA planning graduates of IBA-Sukkur, and the treatment effect $\boldsymbol{\beta}_{\mathbf{1}}$ and $\boldsymbol{\beta}_{\mathbf{2}}$ are conformable parameter vectors, and $\boldsymbol{\varepsilon}$ is disturbance term. The index $m$ denotes the number of categories, which again is five and the index n now denotes the number of students, which is 100 .

\section{Results}

Comparison to the results of table.2.for firms with those in Table.3 for students indicates certain differences between the firms and students responses. To statically test these differences, a general linear model can once again be implemented by redefining the matrix. The model is again of the form

$\mathrm{Y}=+\mathrm{X} 1 \quad 1+\mathrm{X} 2(\mathrm{X} 1) \quad 2+$

Where $\mathrm{Y}=\mathrm{mn} \quad 1$ vector of allocation time mean for student and firms, $\mathrm{X} 1$, is $\mathrm{mn} \quad \mathrm{m}$ vector of amin or treatment. Again 1, 2 are parameters vectors is the disturbance term, $\mathrm{m}=$ number of categories. The five types of firms, sales in 1000 number of employees and the treatment effects, 1, 2 are comfortable parameter vectors and is the disturbance term. The index $m$ denotes the number of categories, which in this case is five, and the index $\mathrm{n}$ denotes the number of firms, which is 56. The first hypothesis is (H1) the allocations of time across activities do not differ for firms. Testing this hypothesis is equivalent to testing the restriction $1=0$. The second hypothesis is (H2), the allocations of time cross activities do not differ by firm characteristics. Testing this hypothesis is equivalent is testing the restriction $=2$.

Table.3. presents the results for the firm or employee model. The row labeled Mean \% Time presents the employers mean responses to the question regarding how junior level students should allocate their time among the five alternative activities to obtain the maximum starting salary offer. These means sum to equal $100 \%$ of the time in equation. The F-test indicates that the First hypothesis is rejected at 0.001 level. Therefore the allocation time across activities do differ for firms and are not uniformly distributed. However only work and internship experiences (WIE) and leadership experiences on campus (LEC) are significantly different from zero at $90 \%$ level. This is evident by associated in values of 0.001 and 0.0012 respectively. In addition to mean of the three categories Technical course work raising GPA and interview preparation do not differ from each other statistically. Among the activities in question, employers recommended that junior students seeking a maximum possible starting salary should spend $38.78 \%$ of salary enhancement time in WIE and $23.5 \%$ of the salary enhancement time in LEC.

The results of the second Hypothesis test are shown in subsequent rows of Table.3. under the heading "Deviation from Mean \% Time " By looking at the $\mathrm{p}$ values associated with F-test statistics and the individual categories, there are no significant differences across different types of firms, with sales, or with number of employees, except for one. The only deviation significantly different zero at $90 \%$ level or above pertains to distributor's view of the lesser importance of WIE. In comparison to an overall employer mean of $45.77 \%$ this deviation is $-17.9 \%$. However, like other employers, food distributor still holds the view that WIE is the most important 
salary enhancement time allocation among the alternates.

Table.3. present the levels for the student model. The row labeled "Mean" percentage Time now presents the student's mean responses to the question of how a junior -level student should allocate time the five alternate's activities to maximize the alary offer. Again these means sum to $100 \%$. The F-test indicates that the second hypothesis is rejected at 0.001 levels. Therefore the students the allocation of the time across activities does differ and are not uniformly distributed. In this case all individual time at allocation activities are significantly different from zero at a $99 \%$ level. This is the evident by the associated $p$ values of 0.0001 or 0.0002 for each of the activities. Among the activities in question, student believe that those seeking a maximum possible starting salary should spend $18 \%$ of the salary enhancement time in technical course work (TCW), $14 \%$ of the salary enhancement time in WIE. The salary enhancement time in interview preparation (IP). Furthermore, in terms of grouping statistics (not shown) the only activities that are not significantly different from on an other are RGPA and interview preparation (IP). On the other hand and perhaps not surprisingly, this column also shows that the RGPA activity declines in importance by $1.53 \%$ of the total salary enhancement time for each additional GPA point that a student possesses.

Regarding the percentage of the time devoted to WIE, the importance of this activity increases by $3.45 \%$ of the total salary enhancement to activity time for each additional GPA point a student possesses. Those planning graduate school immediately viewed WIE as worthy of $4.76 \%$ more of the total salary enhancement time than average. Those planning to attend graduate school after later viewed time devoted to WIE as worthy of $3.66 \%$ less of the total salary enhancement time than average. Regarding time devoted to WIE, students attending the Sukkur-IBA viewed this activity as $4.55 \%$ more important than average. In contrast the regarding time devoted to LEC, students attending Sukkur-IBA viewed this activity as $5 \%$ less important than the average. These last two results showed that Sukkur-IBA students placed less emphasis on WIE, and more emphasis on LEC time. When compare with IBA-Karachi and CBM, employer recommendations for WIE are match closely by IBA-Sukkur-students.

\section{Study Implications}

The focus of this study is on the very specific issue. Namely, how should a junior level student spend his remaining time until graduation to obtain the maximum possible starting salary from the food and manufacture firms. Consequently this study does not address all the major determinants of starting salary. On the basis of this research regarding junior-level students majoring business we can say the following while perspective of Agro-food and manufacture sector employers. These findings can be understood within the context of the debate on human capital versus screening. The human capital school of thoughts holds that higher education enhances earnings because it signals employer that the valuable skills have been learned. In contrast the screening school of thought holds that due solely to college education and completion of higher education, the employer receive a signal that the perspective graduate is above average, again enhance earnings (Wolpin). Consequently one can infer that the emphasis that the employer place on WIE and LEC is that these activities may signal the presence of skills that command a premium in the business world. From the professors perspective the value of internship may improve the students motivation for the future course work and provide a set of experiences in which the place of subsequent course work into richer context. In this sense, having held an internship after BBA -final or MBA-Final can be GPA enhancing force most pleasing the professors. This is perhaps one reason why BBA-and MBA programs often require extensive career experience prior to completing their studies. Business students have more advantage of doing different internship programs compare with all other fields. From the employer's perspective, one way to internship the demand for more internship experience is to take a broader view. Work and leadership experience is not a substitute for classroom experience, but rather a complement. A college degree for the job market is minimum requirement for enter in the job market. Beyond the minimum requirement employers are looking for students who have been exposed to the real work learning experiences. Such learning experiences do not necessary have to occur off-campus on a one student to employer basis.

\section{Conclusion}

The focus of this study is on a very specific issue. Namely how should the junior level students enrolling in MBA program or business studies? We can say the following. While prospective business students of Business Administration Sukkur believe in merit, quality and Excellence. The graduate of IBA-Sukkur compare to other business schools in interior Sindh has a good brand image, which they are producing according to the demand of the market in Pakistan as well overseas. These findings can be understood within the context of the debate on human capital versus screening. The human capital school of thoughts holds that higher education enhances earnings because it signals employers that valuable skills have been learned. In contrast, the screening school of 
thought holds that due solely to college admission and completion of a higher education, the employer receives a signal that the prospects graduate is above average again enhance earnings. From the Professor's perspective, the value of internships may improve the student's motivation for future course work and provide a set of experiences in which to place subsequent course work into richer context. In this sense, having held an internship can be GPA enhancing force most pleasing to Professor's. This is perhaps one reason of MBA graduate who are getting good exposure of market, and as well relationship with the market people. For the employers to place greater our curriculum, they need to better understand what we are teaching and also take active role in assessing student's market knowledge once they completed the internship program from their chosen major.

\section{References}

Barkley, A.P, W.A.Stock, and C.K Sylvie. (1999). Business Graduate Earnings. Am.J.O.A.Economics, 81, November, 785-800.

Broder, J.M., and R.F. Deprey. (1995). Monetary returns to bachelor's degree in Agricultural Economics. Amer.J. Agr.Econ, 77, August, 666-73.

Deaton, A, and J. Mueller. (1980). Economics and Consumer behavior. Cambridge University press.

Economic Survey of Pakistan. (2007-08). Ministry of finance, Government of Pakistan.

FAEIS-food and agriculture education information system. (1998). Enrolment in Agriculture, Renewable Resources, Natural resources and forestry. USDA/CSREES/SERD/Higher education promotion and Texas A \& $M$ University 1999, Fall.

Jaforullah, M. (1993). Asymmetric supply response: evidence from Bangladesh. Journal of Agricultural Economics, 44, 490, 495.

James, E., N. Alsalam, J.C. Conaty, and D.L, to. (1989). College quality and future earning: where should you send your child to college?, Amer.Econ. Rev, 79, May, 247-52.

Jones. E.B. and J.D Jackson. (1990). College Grades and labour Market rewards. J. Human Res, 30, Spring, 253-66.

Lim, S.L. (1999). The supply response of primary producers, Penerbit University Malaysia.

Maitha, J.K. (1970). Productivity response to price, A case study of Kenyan. Coffee East African Economic Review, 23-37.

Ogbu, O.M. Gwetibou, M., (1990). Agricultural supply response in sub-Saharan a critical review of the literature. Afr.Dev.Rev, 2, 83-99.

Preston, W.P., J.M. Broder, and M.C. Almero. (1990). Temporal Analysis of Income Earned by former Agriculture Students. Amer. J. Agric, 72, February, 13-23.

Rao J.M. (1989). Agricultural supply response: a survey Agric. Eco, 3, 1-22.

Wise, D.A. (1975). Academic achievement and job performance. Amer. Econ.Rev, 65, June, 350-66.

Wolpin, K.L. (1977). Education and Screening. Amer. Econ. Rev, 67, December, 949-58. 
Table 1. Description of Surveyed Firms

\begin{tabular}{|c|c|c|c|}
\hline Name of Organization & $\begin{array}{l}\text { No. Of IBIAN } \\
\text { Employed in Various } \\
\text { Organizations }\end{array}$ & $\begin{array}{l}\text { Average } \\
\text { Salaries per person. }\end{array}$ & $\begin{array}{l}\text { Total Number } \\
\text { of Employees }\end{array}$ \\
\hline $\begin{array}{l}\text { Position in Food } \\
\text { Marketing Chain }\end{array}$ & 10 & 25000 & 23,000 \\
\hline NADRA & 19 & $\begin{array}{l}14000 \text { per month } \\
168,000 \text { Annual }\end{array}$ & 15000 \\
\hline Engro Foods & 15 & $\begin{array}{l}24,000 \text { p.m } \\
288,000 \text { p.a }\end{array}$ & 1000 \\
\hline FFC & 02 & $\begin{array}{l}\text { 35,000p.m } \\
\text { 4,20000p.a. }\end{array}$ & 30000 \\
\hline HBL-Zurich & 01 & $\begin{array}{l}\text { 50,000p.m } \\
6,00000 \text { p.a }\end{array}$ & 30000 \\
\hline Askari Bank & 8 & $\begin{array}{l}\text { 20,000p.m } \\
\text { 2,40,000p.a }\end{array}$ & 500000 \\
\hline HBL & 03 & $\begin{array}{l}25,000 \mathrm{p} \cdot \mathrm{m} \\
3,00000\end{array}$ & 1240000 \\
\hline UBL & 03 & $\begin{array}{l}28,000 \mathrm{p} . \mathrm{m} \\
3,36000 \mathrm{p} . \mathrm{a}\end{array}$ & 120000 \\
\hline Bank Al -Falah & 5 & $\begin{array}{l}25,000 \text { p.m } \\
3,00000\end{array}$ & 239000 \\
\hline $\begin{array}{l}\text { Pharma Industries } \\
\text { Gates Pharma }\end{array}$ & 02 & $\begin{array}{l}\text { 40,000p.m } \\
\text { 4,80,000 p.a }\end{array}$ & $\begin{array}{l}2456000 \\
40000\end{array}$ \\
\hline Adventis Pharma & 01 & $\begin{array}{l}\text { 30,000p.m } \\
360,000 \text { p.a }\end{array}$ & 3557882 \\
\hline Hilton Pharma & 02 & $\begin{array}{l}30,000 \text { p.m } \\
360,000 \text { p.a }\end{array}$ & 400000 \\
\hline Novartis & 03 & 23000 & 50000 \\
\hline Telecommunication & 05 & $\begin{array}{l}2,0,000 \text { p.m } \\
240,000 \text { p.a }\end{array}$ & 580000 \\
\hline IBA-Faculty & 05 & $\begin{array}{l}30,000 \text { p.m } \\
360,000 \text { p.a }\end{array}$ & 200 \\
\hline
\end{tabular}


Table 2. Description of Surveyed Students

\begin{tabular}{|l|l|}
\hline Students Characteristics & Mean Standard Deviation \\
\hline Class 1995 Batch & 0.05 \\
Class.96 & $(0.21)$ \\
Class.97 & 0.22 \\
Class.98 & $(0.41)$ \\
Class.99 & 0.40 \\
Class.2000 & $(0.49)$ \\
Class.201 & 0.24 \\
Class.202 & $(0.43)$ \\
Class.2003 & 0.06 \\
Class.2004-05 & $(0.23)$ \\
Class-2005 & 0.07 \\
& $(0.34)$ \\
& 0.072 \\
& $(0.28)$ \\
& 0.076 \\
& $(0.079$ \\
& 0.081 \\
& \\
& 0.080 \\
& $(0.034)$ \\
& 0.770 \\
& $(0.0 .334)$ \\
& 0.885 \\
& $(0.418)$ \\
& 0.6765 \\
& $(0.6765)$ \\
\hline
\end{tabular}


Table 3. General Linear Model Time Allocation Selected By Students to Receive A Maximum Starting Salary

\begin{tabular}{|c|c|c|c|c|c|c|}
\hline & $\begin{array}{l}\text { Technical } \\
\text { Course } \\
\text { Work(TCW) }\end{array}$ & $\begin{array}{l}\text { Raising } \\
\text { GPA } \\
\text { (RGPA) }\end{array}$ & $\begin{array}{l}\text { Work or } \\
\text { Internship } \\
\text { Experience } \\
\text { (WIE) }\end{array}$ & $\begin{array}{l}\text { Leadership } \\
\text { Experience on } \\
\text { Campus(LEC) }\end{array}$ & $\begin{array}{l}\text { Interview } \\
\text { Preparation) }\end{array}$ & F-test \\
\hline $\begin{array}{ll}\text { Mean } & \% \\
\text { Time } & \end{array}$ & $\begin{array}{l}0.1711^{*} \\
(0.0001\end{array}$ & $\begin{array}{l}0.1397^{*} \\
0.0002\end{array}$ & $\begin{array}{l}0.3222^{*} \\
0.0001\end{array}$ & $\begin{array}{l}0.2212^{*} \\
0.0001\end{array}$ & $\begin{array}{l}0.1455^{*} \\
0.0001\end{array}$ & $\begin{array}{l}30.75 \\
0.0001\end{array}$ \\
\hline Deviation & $\begin{array}{ll}\text { From } & \\
\text { Mean } & \% \\
\text { Time } & \\
\end{array}$ & & & & & \\
\hline $\begin{array}{l}\text { Class of } \\
95\end{array}$ & $\begin{array}{l}-0.03369 \\
(0.3307)\end{array}$ & $\begin{array}{l}0.0208 \\
(0.5485)\end{array}$ & $\begin{array}{l}0.0243 \\
(0.4826)\end{array}$ & $\begin{array}{l}-0.0033 \\
(0.9233)\end{array}$ & $\begin{array}{l}-0.0059 \\
(0.8655)\end{array}$ & $\begin{array}{l}0.37 \\
(0.87)\end{array}$ \\
\hline 96 & $\begin{array}{l}-0.03470 \\
(0.2539)\end{array}$ & $\begin{array}{l}0.0410 \\
(0.1787)\end{array}$ & $\begin{array}{l}0.00270 \\
(0.9297)\end{array}$ & $\begin{array}{l}0.0082 \\
(0.7885)\end{array}$ & $\begin{array}{l}0.0009 \\
(0.9770)\end{array}$ & $\begin{array}{l}0.64 \\
(0.67)\end{array}$ \\
\hline 97 & $\begin{array}{l}-0.0473 \\
(0.1132)\end{array}$ & $\begin{array}{l}0.0562 \\
(0.0602)\end{array}$ & $\begin{array}{l}-0.0097 \\
(0.7451)\end{array}$ & $\begin{array}{l}0.0035 \\
(0.9057)\end{array}$ & $\begin{array}{l}0.0027 \\
(0.9287)\end{array}$ & $\begin{array}{l}1.23 \\
(0.29)\end{array}$ \\
\hline 98 & $\begin{array}{l}-0.022 \\
(0.2333)\end{array}$ & $\begin{array}{l}0.0552 \\
(0.12343)\end{array}$ & $\begin{array}{l}0.00453 \\
(0.000543)\end{array}$ & $\begin{array}{l}(0.06675) \\
-00.6756\end{array}$ & $\begin{array}{l}(0.08978) \\
0.06553\end{array}$ & $\begin{array}{l}0.66 \\
(0.65)\end{array}$ \\
\hline 99 & $\begin{array}{l}-0.34555 \\
(0.4543)\end{array}$ & $\begin{array}{l}0.223132 \\
(0.29799)\end{array}$ & $\begin{array}{l}-0.56565 \\
(0.68757)\end{array}$ & $\begin{array}{l}-0.65345 \\
(0.25634)\end{array}$ & $\begin{array}{l}-0.5645 \\
(0.22333)\end{array}$ & $\begin{array}{l}0.70 \\
(0.68)\end{array}$ \\
\hline 2000 & $\begin{array}{l}-0.22345 \\
(0.2334) \\
\end{array}$ & $\begin{array}{l}-0.5757 \\
(0.4363) \\
\end{array}$ & $\begin{array}{l}-0.06675 \\
(0.2345) \\
\end{array}$ & $\begin{array}{l}-0.45452 \\
(0.45434) \\
\end{array}$ & $\begin{array}{l}-0.0655 \\
(0.45643) \\
\end{array}$ & $\begin{array}{l}0.75 \\
(0.72) \\
\end{array}$ \\
\hline 2001 & $\begin{array}{l}-0.300 \\
(0.3794) \\
\end{array}$ & $\begin{array}{l}-0.0543 \\
(0.1269) \\
\end{array}$ & $\begin{array}{l}-0.67867 \\
(0.9315) \\
\end{array}$ & $\begin{array}{l}-0.05645 \\
(0.7055) \\
\end{array}$ & $\begin{array}{l}-0.334 \\
(0.08158)\end{array}$ & $\begin{array}{l}0.80 \\
(0.76) \\
\end{array}$ \\
\hline 2002 & $\begin{array}{l}-0.088 \\
(0.8413)\end{array}$ & $\begin{array}{l}-0.0360 \\
(0.56465)\end{array}$ & $\begin{array}{l}-0.0007 \\
(0.78676)\end{array}$ & $\begin{array}{l}-0.00087 \\
(0.78786)\end{array}$ & $\begin{array}{l}-0.0898 \\
(0.564654)\end{array}$ & $\begin{array}{l}0.85 \\
(0.81)\end{array}$ \\
\hline 2003 & $\begin{array}{l}-0.0678 \\
(0.7857)\end{array}$ & $\begin{array}{l}-0.06876 \\
(0.57657)\end{array}$ & $\begin{array}{l}-0.02786 \\
(0.6868)\end{array}$ & $\begin{array}{l}-0.678687 \\
(0.65589)\end{array}$ & $\begin{array}{l}-0.07979 \\
(0.7896)\end{array}$ & $\begin{array}{l}0.90 \\
(0.85)\end{array}$ \\
\hline 2004 & $\begin{array}{l}-0.0088 \\
(0.8414)\end{array}$ & $\begin{array}{l}-0.0360 \\
(0.4115)\end{array}$ & $\begin{array}{l}-0.0085 \\
(0.56545)\end{array}$ & $\begin{array}{l}-0.07876 \\
(0.267856)\end{array}$ & $\begin{array}{l}-0.022 \\
(0.2333)\end{array}$ & $\begin{array}{l}0.93 \\
(0.89)\end{array}$ \\
\hline 2005 & $\begin{array}{l}-0.0777 \\
(07686) \\
\end{array}$ & $\begin{array}{l}-0.0360 \\
(0.4115)\end{array}$ & $\begin{array}{l}-0.0085 \\
(0.56545)\end{array}$ & $\begin{array}{l}-0.07876 \\
(0.267856)\end{array}$ & $\begin{array}{l}-0.022 \\
(0.2333)\end{array}$ & $\begin{array}{l}0.93 \\
(0.89)\end{array}$ \\
\hline 2006 & $\begin{array}{l}-0.0777 \\
(07686) \\
\end{array}$ & $\begin{array}{l}-0.0360 \\
(0.4115) \\
\end{array}$ & $\begin{array}{l}-0.0085 \\
(0.56545) \\
\end{array}$ & $\begin{array}{l}-0.07876 \\
(0.267856) \\
\end{array}$ & $\begin{array}{l}-0.022 \\
(0.2333) \\
\end{array}$ & $\begin{array}{l}0.93 \\
(0.89) \\
\end{array}$ \\
\hline 2007-08 & $\begin{array}{l}-0.0777 \\
(07686)\end{array}$ & $\begin{array}{l}-0.0360 \\
(0.4115)\end{array}$ & $\begin{array}{l}-0.0085 \\
(0.56545)\end{array}$ & $\begin{array}{l}-0.07876 \\
(0.267856)\end{array}$ & $\begin{array}{l}-0.022 \\
(0.2333)\end{array}$ & $\begin{array}{l}0.93 \\
(0.89)\end{array}$ \\
\hline
\end{tabular}

